\title{
MJN PROPER HEALTH EDUCATION FOR PARENTS BASED ON PARENTS' LIFE EXPERIENCE WITH LONG-TIME INTERNET USE OF ADOLESCENT
}

\author{
Suwarsi Suwarsi ${ }^{1 *}$, Josephine D. Daquioag-Lorica² \\ ${ }^{1}$ School of Nursing, Respati University of Yogyakarta, Indonesia \\ ${ }^{2}$ School of Nursing and Allied Health Sciences, Graduate School, St. Paul University Philippines, \\ Philippines \\ *Corresponding Author's Email: suwarsi@respati.ac.id
}

\begin{abstract}
This study reveals the amount of health education is necessary for parents to form a basis of the experiences of living with prolonged Internet user adolescent. This research can also help as a basic knowledge of preventing health issues between parents and adolescents due to internet use. The study imprinted a qualitative approach specifically towards the descriptive phenomenon. 10 parents ( 5 with boy and 5 with girl children) were Participant who were identified by snowball method with the inclusion criteria of having Internet using adolescents under the age group 13-24 years and use the internet for more than four hours a day. Data was collected through interviews online and face to face and analyzed using Giogi's phenomenological analysis. In the result section, five themes are there and each describes the necessity of health education of the parents who has prolonged Internet using adolescents. The parents are suggested how to manage worry, get rid of feelings of dislike in children, maintain the positive effects, overcome detrimental effect of the internet on children, reduce the frequency of children Internet use through their cell phones. This research can guide healthcare providers to prepare health education materials for parents in the community. Role of parents in society is very much important to prevent the negative effects of internet use.
\end{abstract}

Keywords: Adolescent; Health Education; Internet Use; Parent Experience

\section{INTRODUCTION}

Long-term internet use has been documented to cause problems regardless of age. Parents now a days are becoming concerned about the long-term internet use of their children specially with the pandemic that has affected the world and children's education. Literature shows that the terms for using the internet for a long time in adolesence are "Internet Addiction Disorder (IAD)," "Pathological Internet Use," "Problematic Internet Use," "Excessive Internet Use," and "Compulsive Internet Use" (Widyanto \& Griffiths, 2006). Other names found are Internet addiction or cyberspace addiction, online addiction, net addiction, Internet addicted disorder, and high Internet dependency was also identified (Davis, Flett, \& Besser, 2002; Hur, 2006). Based on Beard (2005) that a person will be disturbed by excessive use of media on psychological aspects, namely mental and emotional states, scholastic interactions, work or activities and their social. Excessive use of the internet creates problems such as the inability of individuals to control their dependence on the Internet, which will lead to feelings of stress, and impaired functional daily activities (Shapira et al., 2000). This opinion is also supported by Rice (2005) that internet dependence is a tendency to use the internet compulsively or continuously which can interfere with an individual's ability to live a normal life or activity under teenager role. As nurses, the researchers see the opportunity to document the parent's experiences in their cry for help regarding their children's use of internet. This also provides a document where healthcare workers can based their interventions.

Most adolescent's mortality and morbidity is anticipated, but adolescents face specific barriers in getting health information or services. Restrictive laws and policies, parental or partner control, limited 
knowledge, distance, cost, lack of confidentiality, and provider bias can all restrict adolescents from getting the care they need to grow and develop in good health. Global situation data from WHO (2020) reported that there are more adolescents in the world than ever before: 1.2 billion, totaling one sixth of the global population. This number is expected to rise through 2050, particularly in low- and middle-income countries where close to $90 \%$ of 10 - to 19 -year-olds live. An estimated 1.1 million adolescents die each year. The leading causes are road traffic injuries, suicide and interpersonal violence. Millions of adolescents also experience illness and injury.

Changes in the media structure in Indonesia, especially with the increasing use of cell phones, have changed the access and use of internet digital media among adolescents, who tend to access the internet in school computer labs; laptop at home, and smartphone during daily activities. The experiences of adolescents in using the internet according has been documented (Hussain \& Griffiths, 2009) and this included online gaming and integration into day-to-day lives; online gaming, excessive play, and problems; addiction; psychosocial impact of online gaming; online gaming, dissociation, and time loss; and online gaming and the alleviation of negative feelings and mood states. When children have an average length of internet use is 3-4 hours a day, this means that the children have become internet addicts (Candrasari, 2008). Twenge, \& Campbell (2018) also found that children use the internet an average of 2-3 hours per day. This means that outside the activities of school children, the internet has become a routine activity that they always do. Much more on weekends internet usage increases because there are no school activities. Practically, teenagers' spare time is more widely used in cyberspace. For children aged 6 years and over, parents should set a special duration that is mutually agreed upon. For example, children can only access gadgets on weekends or a maximum of 2 hours per day rather than four continuous hours (using a cell phone), preferably an hour of rest, according to the American Academy of Pediatrics (2016).

Mafé \& Blas (2006) opined that internet users depend on young age, education and connection with the media. Internet users can also be referred to as ritualist and instrumentalist users. A ritualist internet user, use it for pleasure purposes, especially when he or she may be bored or feel lonely. In contrast, instrumentalist internet users attach great importance to the act of self- gratification which can be fulfilled by browsing a website, tending to seek information to increase knowledge or information.

Characteristics of those who are vulnerable to excessive internet use according to Soule et al., (2003) are those not married, young men, students, gay, middle-aged women, and those with less education; for gender, there is no difference in the length of internet use. Ages between 19 and 24 years are more at risk of becoming Internet addicts than older users (Soule et al., 2003; Thatcher \& Goolam, 2005).

Behind the behaviors of adolescents' use of the internet raises a response from their parents. This response is usually in the form of complaints regarding excessive internet use. Parental responses can be in the form of positive or negative that need to be researched to focus on adolescent problems using the internet for a long time. So why study parents' experiences, this is because of the open interactions that occurs between parents and their children. Parents are living with the adolescents, thus they can be provided with certain capabilities to intervene. The life experience of parents on their child's internet usage behavior and their desire for health education can be the basis for health workers in preparing appropriate materials for health education of families with adolescent children.

This study aims to explore the appropriate health education to be given to parents based on their life experiences with adolescents who use the internet for a long time. Research questions were structured to elicit broad themes about parental experiences: What are the experiences or feelings of parents having children using the internet for a long time? and What do parents want to get in health education for the experience?

\section{METHODOLOGY}

The study used descriptive phenomenological approach. Descriptive phenomenological (Giorgi, 1997) is used when little is known about a problem and to clarify and understand the essential meaning of an interesting phenomenon from their perspective. The design was suitable for exploring the parent's health education needs as they experience living with an adolescent with long-term internet use in Yogyakarta. The participants were 10 parents, one of whom could be the mother or father, where a total of 5 girls and 5 boys were identified through snow ball sampling considering the following inclusion criteria: 
1. Parents aged 35-55 years.

2. Parents have children aged 13-24 years

3. Parents who experience the phenomenon of their children using the internet for more than 4 hours a day.

4. Parents who want to become participants after the researcher explains the course of the research.

The participants were recruited through association of family welfare builders in the community. After which, researchers recruited participants through social media, where these participants often complained about how troublesome it is to have teenagers who frequently play the internet'. When the participant agreed, they were interviewed. Interviews were conducted face-toface or through online media for getting a detailed picture of participants' experiences. Data was gathered though an indept interview with the use of an interview guide. It consisted of four (4) open ended. Field notes was also used in recording observations of the researcher. The study was carried out considering the approval process of the Respati University Yogyakarta, which also included the approval of their Research Ethics Board for the study. Data analysis in this study was carried out using the descriptive phenomenological method developed by Collaizzi (1978).

\section{RESULTS}

Specifically, lts of this study shows that there are five themes that describe the health education needs desired by parents based on parents' life experiences with prolonged internet use of their adolescents These are: managing their worries, applying how to get rid of feelings of dislike for their children, maintaining the positive effects of the internet use, overcoming the negative effects of the long-term internet use and reducing the frequency of children using the internet through their cell phones.

\section{Theme 1: Managing Worries for their Children}

In the first theme, the parents seeing their teenagers playing the internet through their cellphone makes them worried. Parents being aware of what risk the internet use can provide to their children has verbalized this concern. This can been conveyed by the participants as follows:

"Sometimes I worry about what sites are being opened on the internet, I am afraid of porn sites, but I have explained that children should not open them. And as far as I can see the child is obedient"(P1-P9).

In addition to concerns about porn sites that children open, parents are also worried about addiction if their children use the internet for online games, as the participants said:

"There is a feeling of worry, apart from worrying not to let my child open a porn site, a concern arises if the child is dependent on playing online games" (Participant $3, P 7, P 9, P 10)$.

After the feelings of worry that are felt by the parents, the parents specify their need for health education on how to deal with feelings of worry in their children, as illustrated in the transcript as follows:

"I was actually wondering how to solve my worries about my child, I think Ineed to be educated" (P1 to P9).

\section{Theme 2 : Applying How To Get Rid of Feelings of Dislike}

During the interview, all participants expressed feelings of being a little annoyed with their children if they played the internet on their cellphones for too long. This is as written as follows:

"I feel a little annoyed when my daughter continues to surf the internet on her cellphone, so she is not very responsive to her parents" (Participant 1,P 4, P 5, P6).

Feeling a little annoyed because the child is not responsive, and also some children communicate in a high tone if the parent reprimands them. As stated by the participants as follows:

"Sometimes feel a bit annoyed if my child speaks in a high tone when I call him while he is playing the internet on his cellphone" (P3,P7,P8,P9,P10).

After parents express their feelings when children use the internet for a long time daily, then parents specify the need to get rid of feelings of dislike for children. As conveyed as follows:

"how to get rid of this feeling of dislike" (P3,P7,P4,P8,P9,P10).

"I am actually uncomfortable, and want to solve this problem $(P 1, P 4, P 5, P 6)$.

Theme 3 : Maintaining The Positive Effects of The Internet for Children

In this study, they were also asked about the responses of parents about whether there are benefits to 
using the internet in children, the parents said there was a positive effect for the child, as shown in the transcript as follows:

"Actually my child is playing the internet on his cellphone, yes, there is a positive effect for my child too" (P1 - P6).

"I think the positive effect, my child can find information on school materials from the internet" $(P 7, P 8, P 9, P 10)$.

With regard to health education needs, parents expect to be given health education to maintain the positive effects of the internet for their children, as illustrated as follows:

"Happy with the positive impact, and how to maintain a good impact for my child"(P1 to P6).

\section{Theme 4 : Overcoming The Negative Effects of The Internet on Children}

In this study, apart from being asked about the benefits of using the internet for children, the parents were also asked about the responses of parents about the harmful effects of using the internet in children, as stated in the transcript as follows:

"If my child uses the internet, I think there are negative effects such as addiction to playing games or addiction to watching cartoons" $(P 1, P 3, P 4, P 7$, P9,P10).

"If my child uses the internet for a long time, what I feel is the negative effect of the child being lazy to move, and the response when told or invited to communicate by parents is slower "(P1 to P10).

As the participant specified their concerns about the negative effects that parents of the children's use of the internet daily for a long time, they also expressed their desire to be given health education to overcome this problem, as stated as follows:

"would love to have a meeting to be taught how to reduce these negative effects" $(P 1, P 3, P 4, P 7, P 9, P 10)$.

Theme 5: Reducing The Frequency of Children Using The Internet Through their Cell Phones

The responses of parents when using the internet during the Covid 19 pandemic was also explored. And parents shared that frequency of their children using the internet via cellphones is increasing, as illustrated in the transcript as follows:
"Since the Covid 19 pandemic, my child goes to school online, so the frequency of using the internet via cellphone has increased. sometimes interrupted by online learning, interspersed with playing on the internet searching. because my child feels bored studying, usually my child plays the internet at night on his cellphone again" (P1,P3,P4,P5).

"My child is like being addicted to playing online games on a cellphone, not only now at the time of the Pandemic, but before the Pandemic too, especially with the many online games played against other people, my child felt challenged" (P3, P7,P9,P10).

From the results of the interview, all parents complained about the same thing, which was stated as follows:

How do I reduce the frequency of children using the internet through their cellphones ..(P1 - P10)

\section{DISCUSSION}

The concept of "life experience" as a study framework helped in deeper understanding of the experiences of parents when they found out that their child is using the internet for a long time, such as feeling worried, feeling a little annoyed, there have identified the positive and negative benefits, increased internet use, and parents know their child uses the internet on their cellphone.

Our findings indicate the importance of being concerned about the responses of parents who have adolescents who use the daily internet for long periods of time. Several participants stated that there is a feeling of worry for his child if every day his child uses the internet for a long period of time, namely more than 8 hours per day.

Parents who are worried about seeing their children use the internet for a long know that there is a negative impact on their children. In this study, parents' concerns are related to their children opening pornographic sites, addicted to online games, lack of social activity, less concern for conditions at home, and lack of communication. The same is conveyed by Sorbring (2014) in his research that parents with an accurate understanding of their children's negative Internet experiences are those who are the most worried. Parents' worrying about their children use the internet for a long time is real, because the research results (Sorbring, 2014) also stated that the experience of adolescents $80.7 \%$ more 
people accessed Pornography, Violence, or Hate Pages than those who never accessed these sites. The current study showed the same feelings of parents if their children use the internet for a long time, namely that they are worried about their children accessing the internet about pornography, but the concerns of parents in this study do not come to the concern that the internet will make their children make contact with someone dangerous, lose friends, commit bullying, obtaining inaccurate information, obtaining distressing information or joining conflicting groups through certain websites.

Recommendations in managing the identified problems are already being studied. Shared Internet experiences and dropping in on the teenager when she or he is using the Internet have been recommended as strategies for decreasing teenagers' experiences with unwanted content and situations was specified (Cho \& Cheon, 2005). Likewise, Stattin \& Kerr (2000) in this case argued that control and supervision strategies are needed so that parents gain meaningful insights and support adolescent development. Open communication between parents and children, trust and not suspicion and control can be facilitated. It can be facilitative for adolescents who choose to talk about their daily lives, something that is mutually beneficial.

Parents' feelings of concern or annoyed in this study when their children use the internet daily for a long time are felt because of changes seen in their children. These changes in their children are interpreted by parents as th enegative impact internet use for a long time, such as children are more aggressive, less concerned about the environment, and lhave ess physical activity. Feelings of annoyance with children cause their communication to be sparse and feel a little stiff. According to Livingstone \& Helsper, (2008), things that can be done in dealing with communication problems between parents and children due to children's internet use are "sharing online activities", "living around", and "sitting with children" as one type of active mediation combined with "help children when faced with problems" or "Encourage children to explore and learn from the internet". WHO (2021) stated that although adolescence is considered a healthy stage of life, there are significant deaths, illnesses and injuries during adolescence which can be prevented or treated. Only if appropriate intervention can be facilitated.

The results of the Sonck, Nikken, \& de Haa, (2013) study among both parents and children, specified that restrictive technical mediation was more often applied by parents. Positive attitude towards the impact of engaging internet use on their children instead of a riskworrying experience for their children can be managed. Restrictive mediation, involves setting rules that restrict the use of the medium, including restrictions on location or specific content (such as violence or sex), or time. Restrictions may help prevent compulsive media use (van den Eijnden et al., 2010). Thus, this can be utilized by parents if they can be taught how to do it appropriately.

Parents realize that the internet for children does not always have a negative impact, but also has a positive impact. According to parents, their children easily find information, are entertained both through online games and by communicating with friends. The positive impact of internet use on children felt by parents in this study needs an understanding that according to (Shin \& Kang, 2015) online communication activities predict differences in perceptions and behaviors related to online privacy. While online chat was found to be positively associated with privacy concerns, social networking and online gaming were found to increase privacy disclosure intentions and behavior. These findings can provide parents and policymakers a clearer insight into the risks that exist across various online communication platforms, and help them to have more focused communication with teens about issues related to online privacy, and to develop more effective guidelines for adolescents online. In order for the internet to have a positive impact on children and parents, Symons et al., (2020) discussed that both parents contribute individually to the safe use of the internet for their teenagers, which emphasizes the importance of involving both parents in parental mediation research.

Appreciating the positive impact of using the internet for their childrenspecially for online education allowed parents to increase the frequency of internet use for their children. The demands of online learning increased the frequency of internet usage for children due to Covid 19 Pandemic which required them to stay at home. As a result, children can use the internet for more than 9 hours per day. The use of the internet in children benefitted the children in learning, entertainment, and communication with their friends. This prolonged use has an impacted on the lack of physical activity for the child. This is according to Sorbring (2014) indicated that a higher frequency of teenagers' internet use is generally 
linked to greater levels of worry on the part of the parent and specifically, worrying about the teenager open pornography pages, and becoming passive and inactive.

\section{CONCLUSION}

The parents response to their children's prolonged use the internet daily has allowed the emergence of feelings of anxiety, a little annoyance in children, the identification of the negative impact on children and also positive impacts. Considering the increasing frequency of internet use while in home because of the pandemic, parents want health education from healthcare personnel. Thus, the theme where the health education can focus on managing worries, reducing feelings of dislike for children, how to maintain the positive impact of the internet, how to reduce the negative effects and reduce the frequency of daily internet usage of their children. This results can now be utilized by he a health care workers to plan health education content for the parents.

\section{Conflict of Interest}

The authors declare that they have no conflict of interest.

\section{ACKNOWLEDGEMENT}

Researchers would like to thank St. Paul University Philippines for the collaboration in this research. Researchers also did not forget to thank Respati University Yogyakarta, Indonesia for funding support and permission to research. This research has been conducted in a transparent manner and meets research ethics and there is no potential for conflict in the future.

\section{REFERENCES}

American Academy of Pediatrics (2016). Announces New Recommendations for Children's Media Use. Baby Center. Preschooler. Entertainment. Media-Savvy. Retrived from: https://www.healthychildren.org/English/news/ Pages/AAP-Announces-New-Recommendations-for-Childrens-Media-Use.aspx

Beard, K. W. (2005). Internet addiction: a review of current assessment techniques and potential assessment questions. CyberPsychology \& Behavior, 8(1), 7-14.

Candrasari, Y. (2008). Reposisi Peran Perempuan dalam Akses dan Pemanfaatan Teknologi Komunikasi. Prosiding: Transformasi Industri Media dan Komunikasi di Indonesia. Dept. Ilmu Komunikasi FISIP UNAIR.

Cho, C. H., \& Cheon, H. J. (2005). Children's exposure to negative Internet content: Effects of family context. Journal of Broadcasting \& Electronic Media, 49(4), 488-509.

Davis, R. A., Flett, G. L., \& Besser, A. (2002). Validation of a new scale for measuring problematic Internet use: Implications for pre-employment screening. Cyberpsychology \&Behavior, 5(4), 331-345.

Giorgi, A. (1997). The theory and practice, evaluation phenomenological method as qualitative research procedure. Phenomenological Psychology, 28(2), 235-260.

Hur, M. H. (2006). Demographic, habitual, and socioeconomic determinants of Internet addiction disorder: an empirical study of Korean teenagers. Cyberpsychology \& Behavior, 9(5), 514-525.

Hussain, Z., \& Griffiths, M. D. (2009). The attitudes, feelings, and experiences of online gamers: A qualitative analysis. CyberPsychology \& Behavior, 12(6), 747-753.

Livingstone, S., \& Helsper, E. (2008). Parental mediation and children's internet use. Journal of Broadcasting \& Electronic Media, 52(4), 581-599.

Mafe, C. R., \& Blas, S. S. (2006). Explaining Internet dependency: An exploratory study of future purchase intention of Spanish Internet users. Internet Research, 16(4), 380- 397.

Rice, M. (2005). Online addiction. Beijing Review, 48(46), 32-33.

Shapira, N. A., Goldsmith, T. D., Keck Jr, P. E., Khosla, U. M., \& McElroy, S. L. (2000). Psychiatric features of individuals with problematic internet use. Journal of Affective Disorders, 57(1-3), 267-272. 
Shin, W., \& Kang, H. (2015). Adolescents' privacy concerns and information disclosure online: The role of parents and the Internet. Computers in Human Behavior, 54, 114-123.

Sonck, N., Nikken, P., \& de Haan, J. (2013). Determinants of Internet Mediation. Journal of Children and Media, 7(1), 96-113.

Sorbring, E. (2014). Parents' Concerns About Their Teenage Children's Internet Use. Journal of Family Issues, 35(1), $75-96$.

Soule, L. C., Shell, L. W., \& Kleen, B. A. (2003). Exploring Internet addiction: Demographic characteristics and stereotypes of heavy Internet users. Journal of Computer Information Systems, 44(1), 64-73.

Stattin, H., \& Kerr, M. (2000). Parenting monitoring reinterpretation. Child Development, 71(1), 1072-1085.

Symons, K., Vanwesenbeeck, I., Walrave, M., Van Ouytsel, J., \& Ponnet, K. (2020). Parents' Concerns Over Internet Use, Their Engagement in Interaction Restrictions, and Adolescents' Behavior on Social Networking Sites. Youth and Society, 52(8), 1569-1581.

Thatcher, A., \& Goolam, S. (2005). Defining the South African Internet 'addict': Prevalence and biographical profiling of problematic Internet users in South Africa. South African Journal of Psychology, 35(4), 766-792.

Twenge, J. M., \& Campbell, W. K. (2018). Associations between screen time and lower psychological well-being among children and adolescents: Evidence from a population-based study. Preventive Medicine Reports, 12, 271283.

Van den Eijnden, R., Spijkerman, R., Vermulst, A., van Rooy, T., \& Engels, R. (2010). Compulsive internet use among adolescents: Bidirectional parent-child relationships. Journal of Abnormal Child Psychology, 38(1), 77-89.

Widyanto, L., \& Griffiths, M. (2006). Internet addiction: A critical review. International Journal of Mental Health and Addiction, 4(1), 31-51

World Health Organization (WHO)(2020). Adolescent health. Health Topics, WHO, Geneva. Retrieved from: https://www.who.int/health-topics/adolescent-health\#tab=tab_1

World Health Organization (WHO)(2021). Adolescent and young adult health. ). Newsroom, Fact sheets, WHO, Geneva, Switzerland. Retrieved from: https://www.who.int/news-room/fact-sheets/detail/adolescents-healthrisks-and-solutions. 